\title{
Psycho Social Consequences Of Broken Homes On Children: A Study Of Divorced, Separated, Deserted And Blended Families
}

\author{
Ayesha Gul \\ Department of Social Work \\ Sardar Bahadur Khan Women's University \\ Muhammad Nadeemullah \\ Department of Social Work \\ University of Karachi
}

\begin{abstract}
Home is the first and instantaneous unit for every child. He or she is born into and consider as a full member of the home. Home is a recognized group of people who are joined together by marriage. Children from broken families are about five times more likely to suffer damaging mental problems than those whose parents are together. I have selected this topic because it's a main social issue now days. Since the divorce rate is increasing rapidly, it affects the whole life of individual. The purpose of this research is to trace the effects of broken homes on the psycho, social and academic performances of a child. The researcher practiced snowball sampling in order to get through to their respondents. The total respondents on which this research is done are 170 children under the age group 10 to 18 year and selected through simple probability sampling with use of snowball sampling technique from four of the secondary schools with the help of Questionnaire and Interview Schedule. The study found the situation that the ratio avoid to go school and low grades of girls is higher than boys due to financial burdens as girls engage themselves in different income resources to overcome the financial crises. Study also found that due to aggressive nature, the boy often tend towards disobedience and suffers from anxiety after a series of hopeless thoughts towards tackling the different challenges. The study recommended it is possible to have healthy, adjusted kids after a divorce, and it is also possible to have a solid relationship with your children with lots of time together after divorce. And family researches should be conducted, so the psychologists, psychiatrists, sociologists and economists can more work over divorce and its consequences and for the betterment of the society.
\end{abstract}

Keywords: Broken Homes, Divorce, Separation, Personality, Mental disturbance, Psycho Social, Consequences.
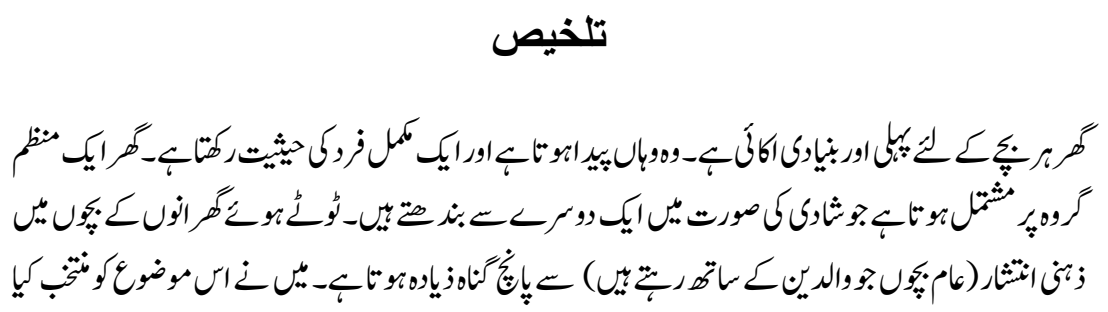


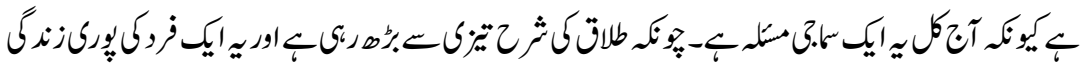

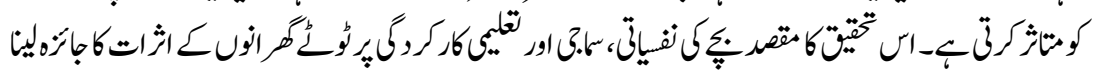

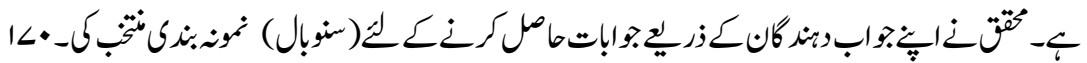

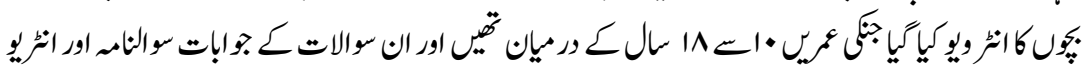

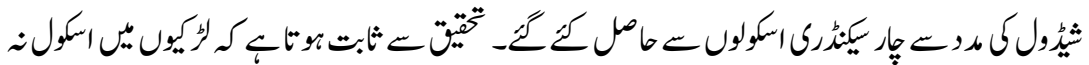

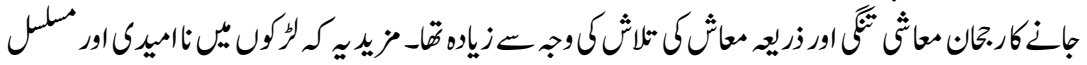

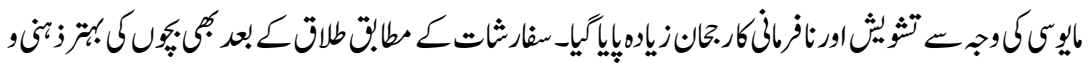

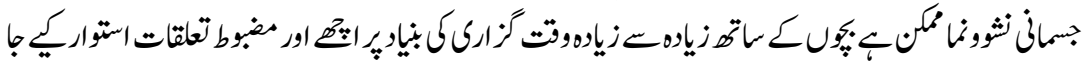

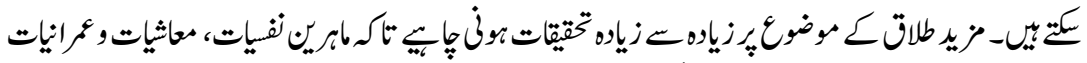

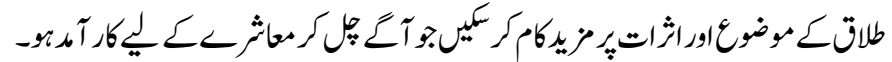

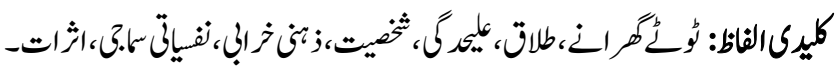

\section{Introduction}

Family is the basic unit of society. This is the most essential element of a country. A home is where a family lives. It may be alternated to the word 'house' but a house is more appropriately referring to the material structure, whereas 'home' refers to the intangible things that connect together the family members. The family is the basis of all civilized society (Stephen\& Barry, 1983).

It is the infinite love and care that keeps together the mother, father and their children. Sydney Smith says: "A comfortable home is a source of great happiness" (Michael, 1987).

A home where good values and virtues are commonly taught by the family. Family providing an environment which is conducive to physical growth and health, the family must also create an atmosphere that would influence the cognitive and psychological growth of its member. If the needs of the individual family members are met, the other members are able to reach out to others in the family, the community, and society as a whole. No matter how ideal a family in the terms of their relationship, there are still hardships and misunderstandings that will come along the way. It is just part of any relationship anyway. But the sad part is when one of the family members gave up and the others have no choice but to accept and let go. Thus, the family starts to be broken.

To family therapist phrase "broken home" can elicit associations such as uncaring, incomplete, separated and torn. Even the term "re-constituted family" means to describe a family of a single parent who remarries, is a problem. Even the seemingly innocent phrase single parent family and one parent family are potentially destructive (Isolina, 1997). 
A Family breakdown may provoke mental disturbances in the partner and their children. Marital crises do not only affect the spouses but usually have a negative impact on the functioning of the whole family. A conflict situation may lead to psychosomatic and psychological illness, behaviour and personality disturbances, sexual dysfunctions or addictions. The reason why a problem emerges among spouses is usually a problem caused by one of the partners nearly always affects also the other and requires conflict solving strategies on both sides. The following factors can influence the quality and stability of relationships: Personality traits (eg: unsolved psychological conflicts, depression, and lack of self-esteem), style of emotional ties (closeness versus distance), biographical experience (eg. age and maturity, divorce of parents), educational and professional resources, and demographic facts (eg. age at which marriage is contracted).

When the parents' divorce, the child knows the family doesn't look the same any more. And it certainly feels good to a child to hear a teacher to call his or her home broken or hear the doctor calling the child victim of divorce or parents stating that their marriage failed. What does all this mean to a child? With negative labels come negative conclusions. The home is broken. The parents are failures. The child is, at least partially, deserted (Isolina, 1997).

A spouse's high expectations to the respective other and unrealistic ideas about marriage and sharing life together are often the reason for conflict. Egocentrism or narcissism is the inability to understand and perceive someone else point of view. It has a negative impact on relationships because of an egocentric person's is primary interest is his or her own needs and the extreme concentration of attention is upon self. Egocentrism is a counter-reaction to deep- rooted feelings of inferiority. An egoistic person's constant demand for attention, is therefore, likely to produce conflicts (Margit, 2010).

When, a couple decides to end up their relationship. Undoubtedly it affects them but the worse affect is on the human personality. Individual has a traumatic effect on his overall personality. Whatever the problem arise between the parents or whatever the reason is behind the broken home. It is very hard for individual to accept the bitter reality that their parents are no more live together. They have lots of question in their mind due to which they are always in depression.

Men who witnessed their fathers abusing their mothers are more likely to become abusive partners themselves. Similarly, women who witnessed their mothers being violent towards their fathers are more likely to be abusive toward their intimates and others (David \& Caroline, 2005).

Childhood is that phase in which the personality of individual is developed, but individual whose both parents are not living together are suffering from severe 
emotional and psychological pain. Their personality is totally destructed by their own parents, relatives and members of society. Moreover at the time of personality development they are trying hard to adjust themselves without their one or both parents. They don't understand how to react on the announcement (of the separation, divorce, or marriage) of the mother/father.

Children do not develop in a vacuum; they develop in the context of their family, neighborhood, community, country and the world. In this context, children are influenced by parents, siblings, other relatives, peers, school and groups which they are a part. The media, community, and culture in which; they grow up and even the events going on in the world influence. They are partly the product of social influences, which affect their social development (Bilal, 2008).

When, a marriage breakdown most men and women experience a diminished capacity to parent. They give less time, provide less discipline, and are less sensitive to their children. Many researches indicates that fatherless children are far more vulnerable to poverty, violence, lawbreaking, drugs, and precocious sexual behaviour; receive less schooling and are more apt to fail in school; and suffer other social pathologies (Frank, 2006).

There are different responses of different individual depend upon the age, intensity of attachment with parents and environment. Sometimes they become angry on small matters, some individuals get panicked, some individuals cry, some insist their parents to not leave them alone. Some individuals try to hide their internal feelings of fear by perceiving that everything will be fine soon.

If we wished to understand the effects of marital dissolution on children, we should compare not merely the two extremes of "happy" families at one end and hostile families at the other; we should also ascertain the effects of death, divorce, separation and desertion on children, moreover, it seems clear that it is the quality of the relation between parents and children that is most important (William, 2007).

There are many different things that separation, divorce or another marriage does to a family and also to the human personality of young ones. Positive effects are very rare in young ones depending on the family members and their priority for them. Broken homes affected negatively on the psychological, social, educational aspect of an individual's life. One thing is clear: a divorced parent who enlists his/her children to help fight the other parent will probably cause their children harm. One parent may try to turn the children against the former spouse.

Mostly the researchers focus on physically broken homes and indicated that many children are the products of broken families. For example a summary conducted; between (1929) and (1958) reported that children processed by officials for 
delinquency are almost twice as likely came from physical broken homes. In the (1940's) a psychiatrist gave psychological tests to one hundred young criminal offenders, and the result showed that many felt hostile, aggressive, and sexually confused as a result of long term exposure to family conflict. Other social scientists indicate that, quarrelling or any form of conflict between parents, is more closely associated with delinquency (David, 1995).

The emotional impact of marriage breakdown is hard on all- the man, the woman, and the child. Particularly the first year is full of shock and fear. The divorced persons are themselves unprepared for the impact of the changed role and status, from married to divorce. Loneliness, anger, depressed feelings, pervasive guilt, towards their children, as well as feeling of resentment against the children for interfering with their freedom and happiness are usual response (Dorothy: 1990).

The visiting parent may use visitation rights to try to lure the child away from the custodial parent. In extreme case, recurring court battles may be fought over the children, or child snatching by the noncustodial parent may occur. This is frightening, confusing, and possibly dangerous to the child (Frank, 2007).

If everyone could simply decide to be happily married, almost no divorced would occur. For most people, the real choice is whether to continue to live together in disharmony, or to divorce. In choosing divorce, they must also choose the complex and often unhappy consequences they and their children will then experience. Most children who experience a divorce are likely to acquire a step parent later on and to live in an intact home. All these experiences do require adjustment, and some are very painful. It is not yet certain, that these experiences have a lasting, destructive effect on most children (William, 2007).

A significant consequence of broken homes is children from them are more likely to become involved that in delinquency and crime. In study after study sociologist find this is to be true. But why should this to be? The single parent (usually woman) must devote a good deal to support and maintenance activities that are at least to some extent shared in two parent's family. Further, she must do so in the absence of psychological or social support. As a result, she is less able to devote time to monitoring and punishment, and is more likely to be involved in negative, abusive contacts with her children (James, 2009).

Children in divorced families are more likely to be anxious, depressed and their mental health problems tend to persist when they become adults. They more have eating problems and disorders. They feel themselves lower in competence, and in fact are likely to be less social and less responsive at home, school and games. Children from broken homes have lower levels of emotional well-being when they become adult. Children also face problems of adjustment. In general the effects of divorce are greater for children who are very young at the time of dissolutions (Robert, 2006). 
Single parenting can occur for several reasons: death, divorce, desertion, and never having been married. A single parent seems to experience common feelings including loneliness, sadness, guilt, and anger. In addition, divorced parents need to decide whether to cooperate with parental contact with the ex-spouse and support contact of the child with ex-spouse and his or her family. Children from single parent households show more problems than children from two parent homes. They have a greater incidence of behaviour problems such as conduct disorders, attention deficit disorders, poor school performance, and emotional problems. Some single parent families are poorly buffered against conflict and stress that may be acute and chronic. They experience multiple stresses operating simultaneously that overwhelm their capacity to cope. Poverty also plays a role in many of the social/psychological problems associated with growing up in a single parent household (Evelyn, 1977).

Boys seem to be more affected by the post divorce absence of the father. In post divorce situation, father seems less likely to be around to solve problems, to discuss standard of conduct, or to enforce discipline. Divorced fathers who remain actively involved in his child's life reduce his son's chances of delinquency (Lassy, 2008).

The boys may escape into the community and find solace in his peer group in what is regarded as normal boy activity. Thus the boy has an avenue of escape from home that is closed to the girl. Away from home, the boy may, however, affiliate with a delinquent group and eventually come to court attention, not for incorrigibility, but usually for some form of stealing.

Girls are more affected by both the quality of the mother's parenting and post divorce parental conflict. It is possible that extreme level of marital conflict may severe as a model to young girls coping with the aftermath of their parent's separation. Since girls spend more of their time at home and are more closely supervised than boys, any latent tension is more likely to burst into open quarrelling and hostility than is true for boys. The girl who attempts to escape from home is less likely to find a free-roving peer group. If she does, or if she runs away by herself, she is considered a delinquent.

A number of experts contend that a broken home is a strong determinant of a child's law-violating behaviour. And because step families, or so called blended families, are less stable than families consisting of two biological parents, an increasing number of children will experience family breakup two or even three times during childhood (Lassy, 2008).

There are various effects of broken families on their personality. We have categorized into two ways. 


\section{Short Term Consequences}

At first, individual experienced emotional well-being and feelings of relief that they were removed from the scene of continuing parental warfare.

Much of time, the short term effects of broken families are negative, according to few researches: they suffered with un-wanted split, feeling of guilt, depression, anxiety, withdrawal, less social and school competence, school problems and etc (John:2005).

Delinquency is characterized by a dichotomous attached/unattached conception of family relationships and broken intact model of family structure (Ronald, 2009). Divorce however; create unintended and often overlooked victims, the children of divorcing parents. Lives of million children are disrupted by divorce. Facing an uncertain future, these children are filled with fears (James, 2009).

\section{Long Term Consequences}

While the parents split-up, individual usually enter adulthood as worried, underachieving, self-deprecating and sometimes angry young men and women. They usually end up with never marrying or getting divorce themselves because such individual didn't grownup with loving, contented families. They didn't know what one ought to be like. These individual have less social competence than do individuals from intact families and are at greater risk for alcohol and drug abuse and are less apt to attend college and the girls are more likely to have early sexual experiences. Such human have low self-esteem and indulge in anti social peers (Brian, 2009).

A study of divorced women found that anger, loneliness, and depression can continue for 10 years or more after a divorce. Although some people can turn a divorce into a positive experience of growth, even they suffer short term negative consequences. Unfortunately, others experience long term trauma. Divorce, separation, and desertion occurred most frequently in the parents of psychopathic personalities and psycho neurotics (Robert, 2006).

Getting over divorce is like learning to walk with one leg after the one has been cut off. Divorce is the amputation of marriage. No matter how necessary it is, it hurts; and there must be a period of recovery before the formerly married can go it alone again.

One new divorcee tells of writing her-self a list of all things she now must learn to do by herself. It is a tragicomic list that includes such items as: Opening bottles, carrying heavy things, going home alone, eating alone, entertaining alone, 
fighting with service companies alone, being sick alone, getting old alone, sleeping alone. Even when some new mate is already on the horizon, there may be many dark clouds to be swept away before the skies of one's life clear once again (Evelyn, 1977).

Remarriages of divorced parents lead to blended families with stepparent and step children. But Cherlin in 1981 suggested, such blended families can involve complications and difficulties for the parents, step parents, and step children involved (E. Mavis, 2009).

Statistically, the marriage of divorced people are somewhat more likely to end in divorce than are first marriages, but this does not mean that a given marriage is any less happy than the first. Remarried divorced individuals have more problems than they had in their first marriages. Yet, most of them rate their rebuilt marriages very happily and most of them stay married (Evelyn, 2009).

Popular assumptions are that parental remarriage has a detrimental effect on children. According to many researchers step children would likely be exhibit mental, emotional and interpersonal problems.

His children, her children, and their children may all be part of the constituted families of the formerly married. Brothers and sisters, half brothers, half sisters, "own" children and stepchildren all share the home of the parents who has been married before. Some of the step children may be occasionally available according to the visiting privileges of the parent and the age of child.

The stereotype of step mother is inconsiderate and lacking in motherliness. We see in our society instances where the step mother relationship has worked out in the best possible way. Even under the most favourable circumstances, however, the role of the step mother is a difficult one (Oliver, 1956). Step children necessarily have at least three parents and sometimes more, which makes for divided authority and the "you" are not my father/mother type rebellion of the older child.

Establishment of good relations between acquired parents and children has been considered one of the most difficult of all human assignments. The general consensus is that very young and growing up children tend to assimilate a new parent more easily than adolescents.

Different scholars review that step children and their new parents, such families experience more stress and less cohesiveness than do families broken by divorce. Stepmothers have more difficult roles to play than do stepfathers, especially when there are adolescents in the family. Stepdaughters tend to have extreme reactions towards their parents (Evelyn, 1977). 
Parenting can make or break the family, a society and a civilization. Civilization building is not ending and not a one time job; rather it is a way of life and a dynamic continuous process. It has a beginning but not end. Civilization continuous to grow, continue and develop. When children are raised in a state of fear and oppression, they become afraid to take risks and afraid to make decisions (Hisham, 2013).

\section{Objectives}

The broad objective of this study was to identify the overall consequences of the family break up on the children. To fulfil this broad objective, the following specific objectives were identified:

1. The effect of broken family on a child's personality and his/her social development.

2. To explore the consequence of family break up on achieving education.

3. To know the pattern of psychological alienation faced by the respondents.

\section{Literature Review}

Family is the fundamental section of society. This is the greatest essential component of a nation and the researcher believes that the number one ingredients on person's happy life are their family, that the parents are the most important source of human's behaviour, which effect to their outlook in life. A broken home can damage and confuse an individual's world. This is natural from infancy through the teen years. Nobody wish to lose the protective feeling that a family contributes. Human undergo an extensive array of emotions to try to navigate. Parents have to contribute as much stability as feasible and include other responsible role models to provide assistance for their child. Different researchers pointed out broken home and its consequences in their studies.

Dr. Fouzia Khurshi and Sufiana Khatoon in (2012) pointed out in their study that the divorce rate is alarmingly increasing worldwide that has deformed the structure of Eastern countries like those of Western. Even the Islamic states are also growing at the same rate in this regard. Addictions of alcohol, gambling or any other such habit can also cause the end of this relationship. Increasing divorce rate is directly proportional to the crime rate in society. Hollowness and low morale overwhelms the children of the divorced parents. Divorce leaves the children morally and emotionally weak and they start showing poor academic performance.

Paul R. Amato and Alan Booth in (1996) pointed out after divorce, the frequency of contact between children and parent left the house, mostly fathers, is decreased. Children's relation with mothers is observed as same after separation in most of 
the cases as before divorce; but in some cases, it is found declining long after divorce. It might be because of guardian mother's remarriage. Children start feeling less intimate with their noncustodial parent if they don't share the same gender with them. The troublesome parent-child relationship continues for the whole course of life. The clash between parent-child relations may have its roots in the pre-divorce period either. This study also shows that the fathers and mothers who later broke up with each other had very harsh attitude with their sons in comparison to the couples who remained together. Children of divorced parents have more behavioral and academic issues than those whose parents never set apart. The parent-child relationship before divorce has strong connection with the dissolution of the parental relations. Divorce does not seem to affect mother's loyalty for children. Marital disputes deviates parents' minds and attention from children that causes so many personality issues in them. Divorce or separation of parents may make the children frustrated and difficult to handle.

Khulna City Corporation Area in (2012) carried out the result that they can be easily manipulated by adults who are involved with various crimes such as drug abuses, child trafficking, and robbery. Most of them mothers in the broken families are either house maid or day labourer. Victims have said that they do not receive support from their parents. A lack of parental love, violent behaviour from family members, frustration, depression, and bad company influence children to be attracted to drugs. As data show in the findings section, their future plans range from becoming a businessman to becoming a nurse. Their dreams are not too unrealistic. If they are given a proper environment to explore their talent, many of them may be able to fulfil their dreams.

Igbinosa Victor Omoruyi in (2014) carried out the results that there is a significant difference between single- parenting and academic performance of the adolescents. There is a significant difference between Socio- economic status of the adolescents and academic performance. And there is a positive relationship between adolescents from broken homes and academic performance.

Marry Joseph in the year (1999) mentioned results $89 \%$ respondents live in slums. Since many crimes occur in slum areas, these children who are already affected by broken families are in a vulnerable. Respondents are reported to have some kind of health problems. Main cause of divorce was the second marriage of the husband. Many of them were drop out from secondary school. Majority were in the categories who obtain low grades. 80 percent cannot afford their school fees. Children said that they feel frustrated. Many of them have reported that they take some kind of drugs.

In (1959) Goode gathered interview data from some four hundred divorcees, who were mothers. His conclusion was necessarily tentative. He questioned the 
assumption that does divorce leads to proper adjustment in children? He summarized that broken home may lead to a child juvenile delinquency. It was found that all mothers were worried about the effects of divorce on their children. Step families and blended families have adverse affect on a child personality according to this research.

\section{Methodology}

\section{Research Design}

The type of research in this thesis was descriptive type of research. Descriptive type of studies provide researchers with a vast amount of information about many social settings .Descriptive designs are more specific in that they direct attention to particular aspects or dimensions of the research target.

\section{Sampling Technique}

The method of sampling used to carry in this study is snowball sampling. Every respondent is being selected according to snowball sampling method because it was difficult to found respondents from the specific universe so, the researchers practiced snowball sampling in order to get through to their respondents.

\section{Population}

The total respondents on which this research is done are 170 according to the snowball sampling method. The sample size for this study consisted of one seventy (170) children under the age group 10 to 18 year.

\section{Universe/Local of the Study}

The selected universes for the research were, SOS Village, Garrison academy, Iqra School and Darul Falah at Alamdar Road Quetta.

\section{Tools for Data Collection}

Researcher used Questionnaire and Interview Schedule techniques for data collection purpose. Researchers used this technique because many of the respondents were children, who had difficulty to fill questionnaire. Another reason to choose this technique was to observe the expressions of respondents to make results accurate. Interview schedule was used for those interviewees, who were available for face-to-face interviews, whereas questionnaires were used for those that were not available for face-to-face interviews. 


\section{Research Questions}

This study sought to provide answers to the following questions:

1. Is there any psychological/emotional and social impact of broken family?

2. And what are the educational impacts of broken family on child academic performance?

\section{Data Analysis}

The data collected were analyzed through the use of simple percentages. Tables were prepared through SPSS and frequencies were put in to these tables through bi-variat and multi-variat tabulation process. Afterwards cross tables were made and variables are tested through bi-variat and multi-variat tabulation method. Data were analyzed using descriptive and inferential statistics. In descriptive statistics, uni-variate analysis was carried out in the form of frequency distributions. Frequency distribution expresses the number of cases within each value of a variable as a percentage or proportion of the total number of cases. It was calculated through following formula

$\begin{array}{lll} & \mathrm{P}= & \frac{\mathrm{F}}{\mathrm{N}} \times 100 \\ \mathrm{P} & = & \text { Percentage } \\ \mathrm{F} & = & \text { Frequency of Classes } \\ \mathrm{N} & = & \text { Total frequency }\end{array}$

The inferential statistics was used during bi-variate analysis to explore the association of two variables and the result was verified.

Table: 1

Age, sex and marital status of the respondents

\begin{tabular}{|l|c|c|c|c|c|c|c|}
\hline \multirow{2}{*}{$\begin{array}{l}\text { Age } \\
\text { (yrs.) }\end{array}$} & \multirow{2}{*}{ Freq. } & \multicolumn{2}{|c|}{ Sex of the respondents } & \multicolumn{3}{|c|}{ Marital Status } & Total \\
\cline { 3 - 8 } & & Male & Female & Single & Engaged & Married & \\
\hline $10-12$ & 13 & 13 & 0 & 13 & 0 & 0 & 13 \\
\hline $13-15$ & 66 & 66 & 0 & 66 & 0 & 0 & 66 \\
\hline $16-18$ & 91 & 11 & 80 & 60 & 20 & 11 & 91 \\
\hline Total & $\mathbf{1 7 0}$ & $\mathbf{9 0}$ & $\mathbf{8 0}$ & $\mathbf{1 3 9}$ & $\mathbf{2 0}$ & $\mathbf{1 1}$ & $\mathbf{1 7 0}$ \\
\hline
\end{tabular}

The above table shows that $13 / 170(7.6 \%)$ respondents were in the age group of $10-12$ years, $66 / 170(38.9 \%)$ were in the age group of $13-15$ years while majority $91 / 170(53.5 \%)$ were in the upper age limit of 16-18 years.

Sex-wise distribution shows that 90/170 (52.9\%) were boys and 80/170 (47.1\%) were girls.

Marital status shows that $139 / 170(81.8 \%)$ were single or unmarried nor engaged, $20 / 170(11.8 \%)$ were engaged and $11 / 170(6.4 \%)$ were married. The table 
highlights the situation of early marriages in Pakistan even in the urban areas. There can be many reasons of early marriages. In Pakistani context, as soon as a girl becomes of age, she is no more considered as a child and mostly, this happens at the age of 13-15 years. The second reason is that in case of single parent or orphan hood, who is there to protect an orphan or fatherless girl of 16-18 years of age if own parents are not there. In Pakistan such girls are, mostly put to work as domestic workers and then every injustice is meted out to them even rape. So why not to marry her out and protect her chastity. The table supports this fact as all the married respondents were girls.

Table: 2

How broken family impacts on studies

\begin{tabular}{|c|c|c|c|c|c|c|c|}
\hline \multirow{2}{*}{$\begin{array}{l}\text { Respondents } \\
\text { Gender }\end{array}$} & \multirow[t]{2}{*}{ Freq. } & \multicolumn{5}{|c|}{ How does broken family impacts your studies } & \multirow[t]{2}{*}{ Total } \\
\hline & & $\begin{array}{c}\text { Lack of } \\
\text { partici-pation }\end{array}$ & $\begin{array}{c}\text { lack of } \\
\text { concen-tration }\end{array}$ & $\begin{array}{l}\text { Avoid to } \\
\text { go school }\end{array}$ & $\begin{array}{c}\begin{array}{c}\text { Low } \\
\text { grades }\end{array} \\
\end{array}$ & None & \\
\hline Male & 90 & 35 & 42 & 13 & 0 & 0 & 90 \\
\hline Female & 80 & 0 & 0 & 32 & 38 & 10 & 80 \\
\hline Total & 170 & 35 & 42 & 45 & 38 & 10 & 170 \\
\hline
\end{tabular}

The above table shows that $90 / 170(52.9 \%)$ respondents were male and amongst them $35 / 90(38.8 \%)$ were reported to take less participation in the class, $42 / 90$ $(46.6 \%)$ were reported to take less concentration in the class, whereas, 13/90 $(14.44 \%)$ respondent were avoiding to go school.

In other category $80 / 170(47.05 \%)$ respondents were female. Amongst those $32 / 80(40 \%)$ reported avoid going to school. 38/80 (47.5\%) respondents were taking low grades in the class, while 10/80 (12.5\%) respondents didn't had any impact of broken family on their studies.

The table highlights the situation that the ratio avoid to go school and low grades of girls is higher than boys due to financial burdens as girls engage themselves in different income resources to overcome the financial crises. On the other hand mothers want their boys to attend the school regularly so they may support them financially in future. But the figure shows that a high ratio of concentration and participation in studies is low in boys due to lack of mental clarity and disturb minds and they are more exposed to society than girls.

Table: 3

\section{Negative impacts of being in broken family}

\begin{tabular}{|l|c|c|c|c|c|c|c|c|c|c|}
\hline $\begin{array}{c}\text { Respondent's } \\
\text { Gender }\end{array}$ & Freq. & \multicolumn{6}{|c|}{ Negative Impacts of Being in Broken Family } & \multirow{2}{*}{ Total } \\
\cline { 3 - 11 } & $\begin{array}{c}\text { Dis- } \\
\text { obedience }\end{array}$ & Anxiety & $\begin{array}{c}\text { Low Self } \\
\text { Esteem }\end{array}$ & $\begin{array}{c}\text { Psychological } \\
\text { Disorder }\end{array}$ & $\begin{array}{c}\text { Over } \\
\text { Confident }\end{array}$ & $\begin{array}{c}\text { Stubborn } \\
\begin{array}{c}\text { All of } \\
\text { these }\end{array}\end{array} \begin{array}{c}\text { None of } \\
\text { these }\end{array}$ & \\
\hline Male & 90 & 36 & 40 & 14 & 0 & 0 & 0 & 0 & 0 & 90 \\
\hline Female & 80 & 0 & 0 & 22 & 18 & 1 & 6 & 30 & 3 & 80 \\
\hline Total & $\mathbf{1 7 0}$ & $\mathbf{3 6}$ & $\mathbf{4 0}$ & $\mathbf{3 6}$ & $\mathbf{1 8}$ & $\mathbf{1}$ & $\mathbf{6}$ & $\mathbf{3 0}$ & $\mathbf{3}$ & $\mathbf{1 7 0}$ \\
\hline
\end{tabular}


The above table shows in boys 40/90 (44\%) were suffering from anxiety, 36/90 (40\%) were reported disobedient, 14/90 (15.5\%) were having low self esteem.

Whereas the girls contained all disorders including low self esteem, psychological disorders, and stubbornness due to over sensitive nature. The table highlights the situation that due to aggressive nature, the boys often tend towards disobedience and suffers from anxiety after a series of hopeless thoughts towards tackling the different challenges.

As a girls often contained inside the house so there is no suitable person or source to express her grieves and expressions which ultimately trigger to such disorders.

\section{Results and Discussion}

In this study, a significant relationship between; mental illness and broken homes was found to exist. Divorce, separation, and desertion were also more frequent in schizophrenia patients. These data would indicate that mental and emotional instability is frequent present in disputed families.

This study sought to provide answers to the following questions:

- Is there any psychological/emotional and social impact of broken family?

- And what are the educational impacts of broken family on child academia?

The details of the analyses and discussion are narrated as under:

\section{Psychological and Social Impacts of Broken Family}

Majority $22.9 \%$ respondents got aggressive while they knew about their parents' Divorce and later second marriage. Majority $73.5 \%$ respondents said yes their daily living is affected due to broken family. High majority $40.6 \%$ respondents feel embarrassed due to their broken family. High majority $23.5 \%$ respondents said that broken family effect on them is anxiety. High number $72.4 \%$ respondents said that they had feeling of insecurity and inferiority complex due to broken family. Majority 47.1\% respondents fight others with no reason to get out of depression. $48.8 \%$ respondents had faced verbal harassment by their step parent $34.7 \%$ respondents faced physical harassment whereas $3.5 \%$ respondents experienced sexual harassment by their step parent.

In dereference to the question about psychological and social impacts of broken homes it was reported that Individuals from broken home have difficulty in making future relations as they cannot trust others easily. They made strong perception that every marital relation has an end as their parents had. Hence, they 
may run from commitment and avoid making relationships. Apart from above mentioned effects one of the worst effects on child's social life is due to society. Our society treats such individual as they commit a crime for being in a broken family. Members in a society are more curious to know about what had happen to them. They ask meaningless and personal questions from children whenever get opportunity. These questions make individual to lose their remaining confidence. Individual try to escape from home. They want to hide themselves and for this reason they spend their time more with friends and indulge in bad activities and they also smoke to relieve from depression. According to social control theory family relationship assume a major role in one of the most powerful models of delinquency. Many of them (boys and girls) are sexually harassed by their step parents who leave an unbearable pain in their whole life.

Popular assumptions are that parental remarriage has a detrimental effect on children. According to many researchers step children would likely be exhibit mental, emotional and interpersonal problems. In (1959) Goode gathered interview data from some four hundred divorcees, who were mothers. His conclusion was necessarily tentative. He questioned the assumption that does divorce leads to proper adjustment in children? He summarized that broken home may lead to a child juvenile delinquency. It was found that all mothers were worried about the effects of divorce on their children. Step families and blended families have adverse affect on a child personality according to this research. A study of 1, 451 patients suffering from various kind of mental illness has given no evidence that broken homes might be related to the onset of schizophrenia. On the other hand the presence of this illness would be almost certain to have a disorganizing effect on the family. Many investigators have pointed that a high incidence of broken homes has been found in the history neurotics. Divorce, separation, and desertion occurred most frequently in the parents of psychopathic personalities and psycho neurotics.

\section{Educational Impacts of Broken Family on Child Academia}

High number $26.5 \%$ respondents said that they avoid going school due to broken family. $62.4 \%$ respondents had received support by their parents in their studies and $37.6 \%$ respondents said that they had not received support by their parents in their studies. High number $66.5 \%$ respondents said they experienced disturbing thoughts during studies. High number $30.0 \%$ respondents got confused in class due to the consequences of broken family.

In response of educational impacts it was reported that Individual especially at the time of disturbance at home cannot study. It can be due to lack of attention towards their children. And also individual they cannot pay attention towards their study as they are very much affected by the fight of their parents. They cannot 
concentrate towards their studies because their mind is diverted to do anything for their parents and make them unite at any cost. Their focus is only their parents. They make everything else as their second priority. Such individual in their class cannot participate as they are upset and they think of their family clashes all the time. They get scared of every one because they think that if someone has asked about their parents, they don't have answer of that question that's why they avoid participating. Usually these individual do not have their separate room because they have to stay with the parent to whom they are living with. Due to this they cannot work on time. They cannot study in their own style as once they were used to with. Dr. Fouzia Khurshi and Sufiana Khatoon in (2012) pointed out in their study that the divorce rate is alarmingly increasing worldwide. Joint family system has also become a cause in this regard. Increasing divorce rate is directly proportional to the crime rate in society. Hollowness and low morale overwhelms the children of the divorced parents. Divorce leaves the children morally and emotionally weak and they start showing poor academic performance. Igbinosa Victor Omoruyi in (2014) carried out the results that there is a significant difference between single- parenting and academic performance of the adolescents. There is a significant difference between Socio- economic status of the adolescents and academic performance. And there is a positive relationship between adolescents from broken homes and academic performance. Marry Joseph in the year (1999) mentioned results 89 percent respondents live in slums. Many of them were drop out from secondary school. Majority were in the categories who obtain low grades. 80 percent cannot afford their school fees.

\section{Conclusions}

It is concluded that family is very important as it shapes our development and personality. The family protects your dignity and takes care of your well being. Family also gives us teachings that guide us throughout our lives and these are the values we carry everywhere we go. In addition, your family comes to your aid during hard times. Family is the building block of a successful person. Family is the first friend; first brick and first memory of a person. It can either make you or break you into pieces. A broken family is typically considered to be a family where one of the parents is missing due to divorce or perhaps the second parent was never part of the family. There are ways to minimize the emotional impact that individual usually feel in these kinds of families. If the single parent really puts forth effort to provide a stable, loving and supportive environment for their individual, it can go a long way to soften the blow of a broken family.

\section{Recommendations}

By taking into consideration the above scenario, certain recommendations to further improve the status of broken families and its victims "specially children" the following recommendation have been put: 
- Family researches should be conducted, so the psychologists, psychiatrists, sociologists and economists can more work over divorce and its consequences and for the betterment of the society.

- Children often believe that their parent's separation is their own fault. Therefore, it is important to tell children that they are not the cause of the separation. Parents need to repeat this number of times.

- It is helpful to tell young children that it's normal to not feel good about what is happening, and that's lots of other children feel this way when their parents become separated. It is also okay for parents to share their emotions with children by saying something like "I am having a hard time since the separation, just like you, but I know it's going to get better after a while "And should not criticize the other parent.

- Tell your children that, anytime they want to talk about the separation, to come to you. It is healthy for children to get out their pent-up emotions in discussions with their parents and to learn that the parents are willing to listen to their feelings and fears.

- Children need parents who care enough to not only give them warmth and nurturance but also set reasonable limits. If children must leave friends behind, it is important for parents to help the children stay in touch by phone or by other mean. Keeping the child busy and involved in the new settings can also keep their minds off the stressful thoughts about the separation.

- After a divorce or separation, parents are as important to children as before the divorce or separation. Divorced parents need to provide children with as much support as possible. Divorced parents can find people who provide practical help and with whom they can talk about their problems. However, seeking out others for support and feedback about problems can make the transition to a single parent family more bearable.

- It is important that efforts should be made to see that girls particularly in their adolescence are given the necessary education to play their role effectively as wife, mother and other interrelated relations that is the education for family life. Family life education has a distinct sociophysiological connotation and is provided mainly through family counseling and specialized courses.

- Divorced parents are advised to help their children talk about and share things about each other so that the children can integrate the two parents lives and life style into a whole some, meaningful system of living. Anger, hurt, jealousy, and other negative emotions may make such an adjustment hard for both adults and children. The divorced father/mother should justify to his/her children that he/she will remain their father/mother regardless of his/her marital status.

- As soon as daily activities in the home make it obvious that one parent is leaving, tell the children. If possible, both parents should be present when 
the children are made aware of the separation to come. The reasons for the separation are very difficult for young children to understand. No matter what parents tell children, children can find reasons to argue against the separation. It is extremely important for parents to tell the children who will take care of them and to describe the specific arrangements for seeing the other parent.

- Parents should pay attention and provide emotional affection to their kids because whatever time they had to spend enjoying has been passed. It's the children's who have to grow up and suffer.

- Children should be involved in social gathering activities so that their social life would not be affected much.

- Parents should help children to express their feelings verbally and nonverbally (i.e. art, music, writing)

\section{References}

Akhtar, Shirina. (2013). Effects of Family Breakup on Children: A Study in Khulna City. Bangladesh e-Journal of Sociology, vol.10:1, pp.138-152, http://www.bangladeshsociology.org/BEJS\%2010.1\%20Final.pdf

Amato, P.R. \& Booth. A. (1996). A Prospective Study of Divorce and Parent-Child Relationships. Journal of Marriage and the Family, vol.58, p.356-365. http://journals.sagepub.com/doi/abs/10.1111/j.1745-6924.2009.01114.x

Avan, Bilal Iqbal. (2008) .Early Child Development. Karachi, Pakistan: Sayed Oxford University Press Mass Printers.

Berger, Ronald J. \& Paul D. (2009). Gregory. Juvenile Delinquency and Justice: Sociological Perspectives. Boulder CO Lynne: Reiner Publisher.

Burhan, John G. \& Wallace Mc Culloch. (1962). Parental Deprivation among Attempted Suicides British Journal of Psychiatric Social Work, vol.6:4, pp.186-191, http://www.eajournals.org

Byrd. E. Oliver, D. M.D. (2005). Family Life Source Book. USA: Stanford University.

Cox. D, Frank \& Kevin Demmit. (2006). Human Intimacy: Marriage, the Family, and Its Meaning. Belmont, CA, USA: Wadsworth Cengage Learning.

Duvall, Evelyn Millis. (1977). Marriage and Family Development. New York: J.B. Lippincott Company Philadelphia. 
F. Ivan Nye. (1957). Child Adjustment in Broken and in Unhappy Unbroken Homes Marriage and Family Living, vol.19:4, pp.356-361, https://www.jstor.org/journal/marrfamilivi?decade $=1950$

Gaffal, Margit (2010). Psychological and Legal Perspectives of Marital Breakdown. New York: Springer Heidelberg Dordrecht.

Goode, J. William. (2007). The Family. New Delhi, India: Prenti e Hall of India Private Limited.

Ganong, L., \& Coleman, M. (1989). A Meta-Analysis of the Effects of Parental Remarriage on Children. Presented at the Society for Research on Child Development Bi-Annual Conference, Kansas City, MO.

Henslin, H. James. (2009). Social Problems: A Down to Earth Approach. USA: Pearson College Division.

Hetherington, Mavis E \& Janl, Deur. (1971). The Effects of Father Absence on Child Development Young Children, vol.26:4, pp.233-248, http://www.eajournals.org

Khurshid, F. Khatoon, S, \& Khurshid, N. (2012). Personal, Social and Psychological Factors Leading Towards Divorce. Interdisciplinary Journal of Contemporary Research in Business, vol.3:11, pp.500-512. http://www.eajournals.org

Knox David, Caroline Schacht (2008). Choices in Relationships an Introduction to Marriage and the Family. USA: Thomson Wadsworth.

Lauer, Robert H. \& Jeanette C. Lauer. (2006). Social Problems and the Quality of Life. New York, NY: McGraw-Hill.

Moore, Stephen, Barry Hendry. (1983). Sociology. NY: Hodder and Stoughton.

Musicks, David. (1995). An Introduction to the Sociology of Juvenile Delinquency. State University of New York: Albany Press.

Omoruyi, Igbinosa Victor. (2014). Influence of Broken Homes on Academic Performance and Personality Development of the Adolescents in Lagos State Metropolis, European Journal of Educational and Development Psychology, vol.2:2, pp.10-23, http://www.eajournals.org/wp-content/uploads/Influenceof-Broken-Homes-on-Academic-Performance-and-Personality-Developmentof-the-Adolescents-in-Lagos-State-Metropolis..pdf 
Pollard, Michael. (1987). The Family. USA: Macdonald \& Co. Publishers Ltd.

Ricci Isolina. (1997). Mom's House Dad's House. New York: Simon and Schuster Inc.

Santrock, John W. (2001). Children. Boston: McGraw-Hill Higher Education.

Santrock, John W.(2005). A Topical Approach to Life-Span Development. Dubuque: McGraw-Hill Higher Education.

Siegel, Lassy J. \& Brandon C. (2008). Welsh Juvenile Delinquency. USA: Thomson Learning, Inc Corporation.

Talib, Hisham, Abdul Hamid, Abu Sulayman \& Omar Alhabib. (2013). Parent Child Relations: A Guide to Raising Children. Herndon: The International Institute of Islamic Thought London, Washington.

Williams, Brian K., Stacey C. Sawyer, \& Carl M. Wahlstrom. (2009). Marriages, Families and Intimate Relationships: A Practical Introduction. Boston, MA: Allyn and Bacon.

Ayesha Gul is an Assistant Professor in the Department of Social Work, Sardar Bahadur Khan Women's University, Quetta Balochistan.

Dr. Muhammad Nadeemullah is an Associate Professor in the Department of Social Work, University of Karachi. 